\title{
EFFECT OF PASTEURIZATION TEMPERATURE ON STABILITY OF AN ACIDIFIED SUGARCANE JUICE BEVERAGE
}

\author{
Efeito da temperatura de pasteurização na estabilidade \\ de caldo de cana acidificado
}

Mariana Kunitake ${ }^{1}$, Cynthia Ditchfield ${ }^{1}$, Carine Silva ${ }^{1}$, Rodrigo Petrus ${ }^{2}$

\begin{abstract}
The shelf life of fresh sugarcane juice is quite limited due to the high rates of microbiological and enzymatic reactions which take place after extraction. In order to evaluate the impact of pasteurization temperature on quality and stability of sugarcane juice with passion fruit pulp, nine batches of sugarcane juice with $4 \mathrm{~g} / 100 \mathrm{~g}$ passion fruit pulp were processed at 85,90 and $95^{\circ} \mathrm{C}$ for $30 \mathrm{~s}$, in triplicate. The pasteurized beverage was aseptically packaged in polyethylene terephthalate (PET) bottles and stored at $7^{\circ} \mathrm{C}$ in the dark. The beverage was characterized by physicochemical tests. Activities of polyphenol oxidase (PPO) and peroxidase (POD) were determined before and after processing. Coliforms and Salmonella tests were carried out to assure the beverage's microbiological safety. Color parameters were measured in the processed juice throughout the storage period. Fifty panelists evaluated the beverage's appearance, aroma, flavor, and overall impression using seven-point hedonic scale tests. Sensory stability was estimated by considering score averages above four and percentages of acceptance above $60 \%$. The $\mathrm{pH}$, soluble solids and titratable acidity of end product ranged from 3.96 to 4.19 , 19.7 to 20.1 ${ }^{\circ}$ Brix, and 0.163 to $0.175 \mathrm{~g} / 100 \mathrm{~g}$ citric acid, respectively. The three processing binomials were effective for PPO inactivation; however, complete POD inactivation was reached at $95{ }^{\circ} \mathrm{C} / 30 \mathrm{~s}$ only. The estimated sensory shelf-lives for sugarcane juice with passion fruit pulp processed at 85,90 and $95^{\circ} \mathrm{C} / 30 \mathrm{~s}$ were 30,40 and 50 days, respectively. Thus, the increase of pasteurization temperature had a positive effect on product's stability.
\end{abstract}

Index terms: Shelf-life, hurdle technology, aseptic filling.

\begin{abstract}
RESUMO
O tempo de vida útil do caldo de cana in natura é bastante limitado em virtude das elevadas taxas de reações microbiológicas e enzimáticas que ocorrem na bebida após a sua extração. Visando à avaliação do impacto da temperatura de pasteurização na qualidade e na estabilidade de caldo de cana acidificado, processaram-se nove lotes de caldo adicionados de polpa de maracujá. Os lotes foram pasteurizados a 85,90 e $95{ }^{\circ} \mathrm{C}$ por $30 \mathrm{~s}$, em triplicata, envasados assepticamente em garrafas de polietileno tereftalato (PET) e estocados a $7{ }^{\circ} \mathrm{C}$, na ausência de luz. Testes físico-químicos foram realizados para caracterizar a bebida. Determinaram-se as atividades de polifenoloxidase (PPO) e peroxidase (POD) antes e após o processamento. Contagens de coliformes e análise de Salmonella foram realizadas para garantir a segurança microbiológica da bebida. Parâmetros de cor foram medidos durante o período de estocagem. Cinquenta provadores avaliaram a aparência, o aroma, o sabor e a aceitação global da bebida por meio de testes de escala hedônica de sete pontos. A estabilidade sensorial foi estimada considerando-se médias de notas acima de quatro e porcentagens de aceitação superiores a $60 \%$. As médias dos valores de pH, de sólidos solúveis e de acidez titulável do produto final variaram entre 3,96 e 4,19;19,7 e 20, ${ }^{\circ}$ Brix, e 0,163 e 0,175 g/100g de ácido cítrico, respectivamente. Os binômios empregados no processamento foram efetivos na inativação da PPO; entretanto, a completa inativação da POD foi alcançada apenas pelo tratamento a $95^{\circ} \mathrm{C} / 30 \mathrm{~s}$. A estabilidade sensorial da bebida processada a 85,90 e $95^{\circ} \mathrm{C} / 30 \mathrm{~s}$ foi estimada em 30, 40 e 50 dias, respectivamente. $\mathrm{O}$ aumento da temperatura de pasteurização impactou positivamente na estabilidade da bebida.
\end{abstract}

Termos para indexação: Vida-de-prateleira, tecnologia dos obstáculos, envase asséptico.

\section{INTRODUCTION}

Sugarcane juice has low acidity, high water activity and high sugar content and therefore deteriorates rapidly even when refrigerated (Yusof et al., 2000). Poor sanitary conditions during extraction also contribute to a fast deterioration of product's quality resulting in changes in appearance and flavor. In order to extend the product's shelf life is necessary to employ technologies to control the factors responsible for juice's deterioration.
The chemical, physical, sensory and nutritional attributes of sugarcane juice are affected by several factors that can be physical (light, heat), chemical $\left(\mathrm{O}_{2}\right)$, biochemical (enzymes) and/or biological (microorganisms, insects). Reduction of $\mathrm{pH}$ below 4.6 is an important action to inhibit growth of most pathogenic microorganisms. Addition of an acid fruit pulp acts as a barrier, preserving the beverage (Silva et al., 2007), though the development of filamentous molds, yeasts and aciduric bacteria, which can be present in natural sugarcane microflora, is favored.

\footnotetext{
${ }^{1}$ Universidade de São Paulo/USP - Faculdade de Zootecnia e Engenharia de Alimentos - Pirassununga - SP - Brasil

2Universidade de São Paulo/USP - Faculdade de Zootecnia e Engenharia de Alimentos - Pirassununga - SP - Brasil - rpetrus@usp.br

Received in july 25, 2014 and approved in september 1, 2014
}

Ciênc. Agrotec., Lavras, v.38, n.6, p.554-561, nov./dez., 2014 
Adoption of proper handling practices by sugarcane juice processors is essential to avoid contamination with pathogenic microorganisms (Vanzo; Azevedo, 2003).

Darkening of sugarcane juice occurs by formation of brown pigments by enzymatic (oxidation of phenolic compounds forming melanin) and non-enzymatic reactions (Maillard reaction, thermal and alkaline degradation and sugar condensation). During juice extraction exposure to oxygen initiates enzymatic browning caused by the activity of peroxidase (POD) and polyphenol oxidase (PPO) (Qudsieh et al., 2002; Vanzo; Azevedo, 2003). Both enzymes can be denatured by heat, reducing their activity and thus improving beverage stability, though POD has been found to be more resistant to thermal treatment than PPO in sugarcane juice (Bucheli; Robinson, 1994). Prati, Moretti and Cardello (2005) have accomplished sugarcane juice pasteurization with and without addition of fruit juices, but the impact of pasteurization temperature on the sensory stability of sugarcane juice with passion fruit pulp, aseptically packed in plastic bottles has not been addressed. In this way, this study was undertaken to evaluate the effect of three pasteurization temperatures on the sensory stability of sugarcane juice acidified with passion fruit pulp and stored at $7{ }^{\circ} \mathrm{C}$ as determined by the sensory scores obtained for appearance, aroma, flavor and overall impression.

\section{MATERIAL AND METHODS}

\section{Raw materials}

Sugarcane (Sacharum officinarum) cultivar SP3250 was supplied by Tecnocana Sugarcane Technology Inc (Santa Cruz das Palmeiras, SP, Brazil). The juice was extracted and processed in a pilot plant at the Department of Food Engineering, University of São Paulo, located approximately $30 \mathrm{~km}$ from the cultivation site. Pasteurized and frozen yellow passion fruit pulp (Passiflora edulis) was acquired from the local market, processed by DeMarchi (Jundiaí, SP, Brazil).

\section{Processing}

Sugarcane was cut, scraped and then immersed in a sodium hypochlorite $(\mathrm{NaClO})$ solution containing $30 \mathrm{mg} / \mathrm{L}$ free residual chlorine (FRC) for $20 \mathrm{~min}$ at a temperature of about $25^{\circ} \mathrm{C}$. Subsequently sugarcane juice was extracted in a stainless steel electric cylinder mill and $4 \mathrm{~g} / 100 \mathrm{~g}$ passion fruit pulp was added to the extracted juice, immediately after extraction to reduce juice $\mathrm{pH}$ and inhibit PPO activity, thus obtaining an acidified sugarcane juice with a $\mathrm{pH}$ of about 4.0.
Acidified juice was thermally processed in a plate heat exchanger (Sumá Indústria e Comércio Ltda, Campinas, SP, Brazil) composed of regeneration, heating, holding and cooling sections, with a nominal capacity of $300 \mathrm{~L} / \mathrm{h}$. The pasteurization binomials were 85, 90 and 95 ${ }^{\circ} \mathrm{C}$ for $30 \mathrm{~s}$ and three alternated replicates were conducted for each condition. The juice was filtered, preheated to a temperature of about $50{ }^{\circ} \mathrm{C}$, homogenized at 150 Bar in a single stage homogenizer (Artepeças P\&B São Paulo, SP, Brazil), heated to the pasteurization temperature, cooled to approximately $8{ }^{\circ} \mathrm{C}$ and pumped to an insulated buffer tank. A stainless steel, ISO Class 5 unidirectional air-flow cabin (Veco, Campinas, SP, Brazil) was used for the beverage's aseptic filling into transparent $320 \mathrm{~mL}$ PET bottles, which were previously decontaminated by dipping in a $0.05 \%(\mathrm{v} / \mathrm{v})$ peracetic acid (PAA) solution at $50{ }^{\circ} \mathrm{C}$ for $30 \mathrm{~min}$.

\section{Physicochemical tests}

Physicochemical tests were performed as determined by AOAC International (AOAC, 2007) as follows. The $\mathrm{pH}$ was determined using a digital meter Analyzer model $300 \mathrm{M}$, the soluble solids content (expressed as ${ }^{\circ}$ Brix) was determined using a Reichert AR 200 portable digital refractometer and the titratable acidity (expressed as \% citric acid) determined by titration with $0.1 \mathrm{~N} \mathrm{NaOH}$.

Samples of processed sugarcane juice, kept at 7 ${ }^{\circ} \mathrm{C}$ for about 60 days, were submitted to physicochemical tests, determination of PPO and POD activities, Coliforms and Salmonella analysis only once after processing. Measurement of color parameters and sensory analysis, to estimate the product's stability, were monthly performed.

\section{Determination of enzymatic activity}

PPO and POD activities were determined according to the methods described by Campos and Silveira (2003). For the PPO activity, the phosphate buffer (pH 6.0) and catechol were added to an aliquot of the sample and incubated at $30{ }^{\circ} \mathrm{C}$ for $30 \mathrm{~min}$. The reaction was then terminated with perchloric acid, the absorbance was read in a spectrophotometer at $395 \mathrm{~nm}$. For the POD activity, phosphate buffer ( $\mathrm{pH} 5.0$ ), hydrogen peroxide, an alcohol solution of guaiacol that was incubated at $30{ }^{\circ} \mathrm{C}$ for $15 \mathrm{~min}$. The reaction was then terminated with sodium metabisulfite. Absorbance was read in a spectrophotometer at $470 \mathrm{~nm}$. A blank absorbance of sugarcane juice added to the phosphate buffer solution (substitute for the reagents) was determined.

Enzyme activity was expressed in $\mathrm{U} / \mathrm{mL}$ with one unit equivalent to a variation of 0.001 absorbance per 
minute per $\mathrm{mL}$ of sample. The equation 1 was applied to calculate the enzyme activity:

$$
\operatorname{Activity}(U / m l)=\frac{\left(A b_{\text {sample }}-A b_{\text {blank }}\right)}{0.001 \times t}
$$

where $A b_{\text {sample }}$ is the sample absorbance; $A b_{\text {blank }}$ is the blank absorbance; and the incubation time of sample with reagents $(\mathrm{min})$.

\section{Microbiological tests}

Coliforms and Salmonella tests were carried out in compliance with Brazilian Regulations, resolution number 12 from 2 January 2001, which requires that pasteurized and chilled pure sugarcane juice must present less than 10 coliforms at $45^{\circ} \mathrm{C} / \mathrm{mL}$ and absence of Salmonella sp. $/ 25$ $\mathrm{mL}$ (Brasil, 2001).

Coliforms tests were performed according to the most probable number (MPN) method. For Salmonella analysis, the 1-2 Test ${ }^{\circledR}$ from BioControl was used. This test is a rapid analysis kit for the detection of mobile species of Salmonella in food, and it has been endorsed by the Association of Official Agricultural Chemists (AOAC) official method 989.13. The test is based on Salmonella immobilization in motility media using polyvalent $\mathrm{H}$ (flagellar) antibodies. The immobilization of mobile species of Salmonella results in the formation of a visible and well-defined band.

\section{Measurement of color}

Color parameters were measured in the processed juice throughout the storage period. A colorimeter (UltraScan model SN7877, Hunterlab, Hunter Associates Laboratory Inc., Reston, VA, U.S.A.) and the CIELab coordinates were measured using D65 illuminant and standard observer $\left(10^{\circ}\right)$. Three measurements were taken for each sample. Results for samples processed at different temperatures were compared as well as the variations observed along the storage period.

\section{Sensory tests}

The processed juice was submitted to sensory evaluation tests, using a seven-point hedonic scale, as described by Dutcosky (2013). The attributes appearance, aroma, flavor and overall impression were evaluated by 50 panelists, consumers of sugarcane juice. The juice was served at a temperature of about $12{ }^{\circ} \mathrm{C}$. To estimate the sensory stability of the juice averages of above four points and at least $60 \%$ of acceptance were adopted as limit values. Sensory tests were performed in approximately 10 day intervals during the 60 days of storage at $7{ }^{\circ} \mathrm{C}$. Processed sugarcane juice samples, used as control, were kept at $-18{ }^{\circ} \mathrm{C}$ throughout the sensory stability study. Sensory tests were conducted every 10 days.

\section{Statistical analysis}

The statistical software program SAS 9.1 was used to perform Analysis of Variance (ANOVA) with a $5 \%$ confidence level and comparison of means by the Tukey test.

\section{RESULTS AND DISCUSSION}

As previously mentioned, nine batches of sugarcane juice with passion fruit pulp were processed, as follows: R1 (batches pasteurized at $85{ }^{\circ} \mathrm{C} / 30 \mathrm{~s}$ ), R2 (batches pasteurized at $90{ }^{\circ} \mathrm{C} / 30 \mathrm{~s}$ ) and $\mathrm{R} 3$ (batches pasteurized at $95^{\circ} \mathrm{C} / 30 \mathrm{~s}$ ).

\section{Physicochemical characterization}

The means and standard deviations of the results obtained in the physicochemical tests are shown in table 1 , for the three batches of each replicate.

According to results shown in table 1, there were no statistic differences among mean values obtained from both fresh sugarcane juice and acidified juice, regarding the extraction yield, $\mathrm{pH}$, soluble solids and titratable acidity. Some differences in the characteristics of the sugarcane juice may be attributed to variations in the plant composition due to different periods of planting, harvesting times, climatic conditions and maturation stages (Stone; Sidel, 1985), in spite of the fact that the raw material batches belonged to the same cultivar and originated from the same production source.

Mao, Xu and Que (2007) found an average yield of $70.8 \%$. The difference between this result and that of the present study may be related to the sugarcane variety used, its maturation stage and the juice extraction method. Higher levels are usually obtained on industrial scale and are made possible by the enzymatic treatment of the bagasse.

A pH below 4.6 classifies the sugarcane juice with passion fruit pulp added as an acidified beverage, which favors microbiological stability and somewhat inhibits enzymatic action, especially the PPO system which has an optimum performance $\mathrm{pH}$ close to 7.2. Moreover, the citric acid in the passion fruit pulp complexes with the copper $\left(\mathrm{Cu}^{2+}\right)$ present in the PPO active site, therefore inhibiting enzymatic browning of the juice (Gomes et al., 2001). 
The addition of acid fruit pulps, such as passion fruit, to sugarcane juice in small proportions also improves the sensory quality of the beverage. Acid fruit pulps promote a change in the relationship between the soluble solids content and the titratable acidity, thus softening the perception of sweetness and providing a refreshing taste (Thé et al., 2001; Matsuura et al., 2004).

\section{Enzymatic activity}

PPO and POD activities in fresh (natural) sugarcane juice varied between 40.3 and $40.9 \mathrm{U} / \mathrm{mL}$, and between 100.2 and $226.1 \mathrm{U} / \mathrm{mL}$; respectively. After addition of passion fruit pulp PPO activity reduced to between 17.2 and $27.8 \mathrm{U} / \mathrm{mL}$ while POD activity was between 107.9 and $163.4 \mathrm{U} / \mathrm{mL}$. PPO was inactivated by all the pasteurization temperatures $(85,90$ and 95 ${ }^{\circ} \mathrm{C}$ ) since no residual activity was detected in processed samples. On the other hand, POD presented residual activities between 0.1 and $17.9 \mathrm{U} / \mathrm{mL}$. These results demonstrate that the three time/temperature binomials effectively inactivated PPO, but to inactivate POD it is necessary to apply most severe binomial $\left(95^{\circ} \mathrm{C}\right.$ for $30 \mathrm{~s}$ ), as reported by Brito et al. (2005). POD stability is decreased by lowering the $\mathrm{pH}$, which favors its inactivation. The variation in enzyme activity can be attributed to raw material composition variability, which is common in vegetable products.

Mao, Xu and Que (2007) reported that PPO activity converts phenolic compounds into brown colored polymers, which causes darkening when sugarcane is crushed. Despite the PPO inactivation during pasteurization alterations in color were still observed, suggesting that other mechanisms, like chlorophyll degradation also occur. The results demonstrate that the characteristics of the raw materials are significantly affected by the harvest period and therefore the industrial process must consider this.Sugarcane juice browning is initiated by the enzymatic oxidation of phenolic compounds, which forms dark, insoluble pigments; therefore, the quantity and availability of phenolic compounds in the presence of oxygen is a major factor in the analysis of the beverage browning. Moreover, high enzymatic activity increases the browning speed, decreasing the acceptability of the beverage. Therefore, it is essential to inactivate the enzymes in the beverage.

\section{Microbiological tests}

Table 2 shows the results for the analysis of coliforms and Salmonella in the pasteurized beverage samples.

The coliforms at $(35$ and 45$){ }^{\circ} \mathrm{C}$ mean counts were below $4 \mathrm{MPN} / \mathrm{mL}$ for replicates 1,2 and 3. All batches processed in the present study complied with Brazilian Regulations, which states that the beverage must present a coliform count at $45{ }^{\circ} \mathrm{C}$ below 10 MPN $/ \mathrm{mL}$ and absence of Salmonella sp. in $25 \mathrm{~mL}$ of sample (Brasil, 2001). Pshychrotrophic bacteria counts throughout the 60 days storage period varied from (1 to 47) $\mathrm{CFU} / \mathrm{mL}$, while yeasts and molds counts ranged from (1 to 23) CFU/mL. These results indicate that the product presented microbiological stability when kept at $7{ }^{\circ} \mathrm{C}$.

Table 1 - Average physicochemical characteristics of the acidified sugarcane juice beverage processed in each replicate.

\begin{tabular}{cccc}
\hline & $\mathrm{R} 1$ & $\mathrm{R} 2$ & $\mathrm{R} 3$ \\
\cline { 2 - 4 } FRESH SUGARCANE JUICE & & & \\
Extraction yield $\left.{ }^{1} \%\right)$ & $54.7 \mathrm{a} \pm 5.5$ & $54.9 \mathrm{a} \pm 5.5$ & $52.1 \mathrm{a} \pm 5.9$ \\
$\mathrm{pH}$ & $5.16 \mathrm{a} \pm 0.16$ & $5.27 \mathrm{a} \pm 0.08$ & $5.27 \mathrm{a} \pm 0.31$ \\
Soluble solids ( ${ }^{\circ}$ Brix) & $21.1 \mathrm{a} \pm 2.2$ & $18.3 \mathrm{a} \pm 4.0$ & $20.3 \mathrm{a} \pm 3.2$ \\
Titratable acidity (\% citric acid) & $0.052 \mathrm{a} \pm 0.015$ & $0.050 \mathrm{a} \pm 0.009$ & $0.047 \mathrm{a} \pm 0.011$ \\
\hline ACIDIFIED JUICE & & \\
$\mathrm{pH}$ & $4.19 \mathrm{a} \pm 0.16$ & $4.07 \mathrm{a} \pm 0.21$ & $3.96 \mathrm{a} \pm 0.17$ \\
Soluble solids ( ${ }^{\circ}$ Brix) & $20.1 \mathrm{a} \pm 2.6$ & $20.1 \mathrm{a} \pm 4.6$ & $19.7 \mathrm{a} \pm 2.5$ \\
Titratable acidity (\% citric acid) & $0.175 \mathrm{a} \pm 0.033$ & $0.163 \mathrm{a} \pm 0.013$ & $0.167 \mathrm{a} \pm 0.046$ \\
\hline
\end{tabular}

$\mathrm{R} 1$ - average of batches 1,4 and 7 (pasteurized at $85^{\circ} \mathrm{C} / 30 \mathrm{~s}$ ), R2 - average of batches 2,5 and 8 (pasteurized at $90^{\circ} \mathrm{C} / 30 \mathrm{~s}$ ), R3 average of batches 3,6 and 9 (pasteurized at $95^{\circ} \mathrm{C} / 30 \mathrm{~s}$ ), ${ }^{1}$ In relation to peeled sugarcane. Mean values followed by the same letter, in the same row, are not different ( $\mathrm{p}>0.05)$. 


\section{Beverage color}

Table 3 presents the results for observed variation in CIELab color parameters when compared to the unprocessed beverage for each processing temperature.

Processed beverages presented higher $\mathrm{L}$ values than the unprocessed ones, indicating that they had a lighter color. Processing at $(90$ or 95$){ }^{\circ} \mathrm{C}$ results in a significant increase in the $\mathrm{L}$ value when compared to the beverages processed at $85^{\circ} \mathrm{C}$. This may be due to a greater enzyme inactivation at the higher processing temperatures. For "a" and "b" values significant differences were not found for different processing temperatures. A large variability is observed for the results probably because of the variations in raw material composition.

Figure 1 shows the variation in color parameters of the processed beverage during the storage period. It can be observed that all batches except 4 and 5 were darker after 4 weeks storage. Variations in $\Delta$ a were slight and a definite trend could not be observed. For replicates 2 and 3 an increase in processing temperature results in higher $\Delta \mathrm{b}$ values, indicating a slightly stronger yellow color. Comparison of $\mathrm{L}$ values for batches 1, 2 and 3 show that the beverage was significantly darker after 4 weeks storage and further increase in the storage period maintained this difference. The "a" and "b" color parameters both tend to present a slight increase during storage but a definite trend could not be established. Enzyme activity after processing, particularly for peroxidase (higher thermal resistance) may be responsible for the color changes observed. Beverage appearance scores seem to be related to the color parameter values. Lower sensory scores were observed for beverages with higher "a" values (shift towards red color). For batch 6 for example after 4 weeks storage the average appearance scores were statistically similar to the freshly processed beverage. The color parameters indicate a significant decrease in the $\mathrm{L}$ value after 4 weeks storage but no significant difference for "a" and " $b$ " values. After 8 weeks storage the $\mathrm{L}$ value maintained the difference, the " $a$ " value increased significantly and the "b" value presented no significant difference (with respect to the freshly processed beverage). However average appearance scores were significantly lower after 8 weeks storage. This same trend can be observed for all the processed batches. It must be noted that sensory evaluation of appearance involves other attributes like homogeneity of sample and also that color change is a combination of the $\mathrm{L}$, "a" and "b" values.

Beverage stability is commonly affected by many intrinsic and extrinsic factors; therefore, sensory analysis is an essential and rapid consumer response tool to evaluate the effect of procedures and treatments performed on the product. Table 4 presents results obtained for the hedonic scale tests of the three replicates carried out at the beginning, middle and end of the storage period. The values in bold indicate acceptance percentages $\leq 60 \%$.

The results shown in table 4 demonstrate that the batches processed at 85,90 , and $95^{\circ} \mathrm{C}$ for $30 \mathrm{~s}$ initially obtained high sensory acceptance scores. The acceptability of the beverages processed in all three conditions initially varied from 82 to $99 \%$ for all tested attributes. According to Teixeira, Meinert and Barbetta (1987) and Dutcosky (2013), approval scores above $70 \%$ indicate high acceptance of the product.

Table 2 - Microbial counts (MPN/mL) in sugarcane juice with passion fruit pulp, pasteurized and aseptically bottled.

\begin{tabular}{cccc}
\hline Replicate & $\mathrm{R} 1$ & $\mathrm{R} 2$ & $\mathrm{R} 3$ \\
\hline Coliforms at $35^{\circ} \mathrm{C}$ & $3.9 \pm 1.6$ & $3.8 \pm 1.4$ & $3.0 \pm 0.0$ \\
Coliforms at $45^{\circ} \mathrm{C}$ & $<3.0$ & $<3.0$ & $<3.0$ \\
Salmonella sp. (in $25 \mathrm{~mL})$ & Absent & Absent & Absent \\
\hline
\end{tabular}

$\mathrm{R} 1$ - average of batches 1,4 and 7 (pasteurized at $85^{\circ} \mathrm{C} / 30 \mathrm{~s}$ ), R2 - average of batches 2,5 and 8 (pasteurized at $90^{\circ} \mathrm{C} / 30 \mathrm{~s}$ ), R3 average of batches 3,6 and 9 (pasteurized at $95^{\circ} \mathrm{C} / 30 \mathrm{~s}$ ).

Table 3 - Comparison of the variation in CIELab color parameters in relation to unprocessed beverage at each processing temperature.

\begin{tabular}{cccc}
\hline Processing temperature $\left({ }^{\circ} \mathrm{C}\right)$ & $\Delta \mathrm{L}^{1}$ & $\Delta \mathrm{a}^{1}$ & $\Delta \mathrm{b}^{1}$ \\
\hline 85 & $2 \mathrm{a} \pm 2$ & $-0.1 \mathrm{a} \pm 0.5$ & $0.6 \mathrm{a} \pm 1.8$ \\
90 & $6 \mathrm{~b} \pm 4$ & $-0.3 \mathrm{a} \pm 0.3$ & $1 \mathrm{a} \pm 1$ \\
95 & $6 \mathrm{~b} \pm 2$ & $-0.1 \mathrm{a} \pm 0.6$ & $0.0 \mathrm{a} \pm 0.5$ \\
\hline
\end{tabular}

${ }^{1}$ Averages of three batches, in the same column, followed by the same letter do not differ at 5\% significance level.

Ciênc. Agrotec., Lavras, v.38, n.6, p.554-561, nov./dez., 2014 
The average scores and acceptance percentages of the samples stored at $7{ }^{\circ} \mathrm{C}$ and of the control samples were similar up to 30 days of storage. After a 60 day storage period the acceptance scores reduced significantly, especially for the batches pasteurized at $85^{\circ} \mathrm{C}$, suggesting a higher quality degradation of the beverage processed at this temperature.

\section{Estimation of sensory stability}

The values obtained for estimating sensory stability of the processed sugarcane juice stored at $7{ }^{\circ} \mathrm{C}$ in the dark, according to acceptance percentage shown in table 4, were 30,40 and 50days for pasteurization at 85, 90 and $95^{\circ} \mathrm{C} / 30 \mathrm{~s}$, respectively.In this way, the sensory stability of the beverage was positively impacted by increasing pasteurization temperature, probably due to enzyme inactivation (Qudsieh et al., 2002). It seems evident that the higher pasteurization temperature the longer shelf life. Nevertheless, for some food products such as pasteurized milk, the reverse situation applies; shelf life is adversely affected (Cromie, 1991).

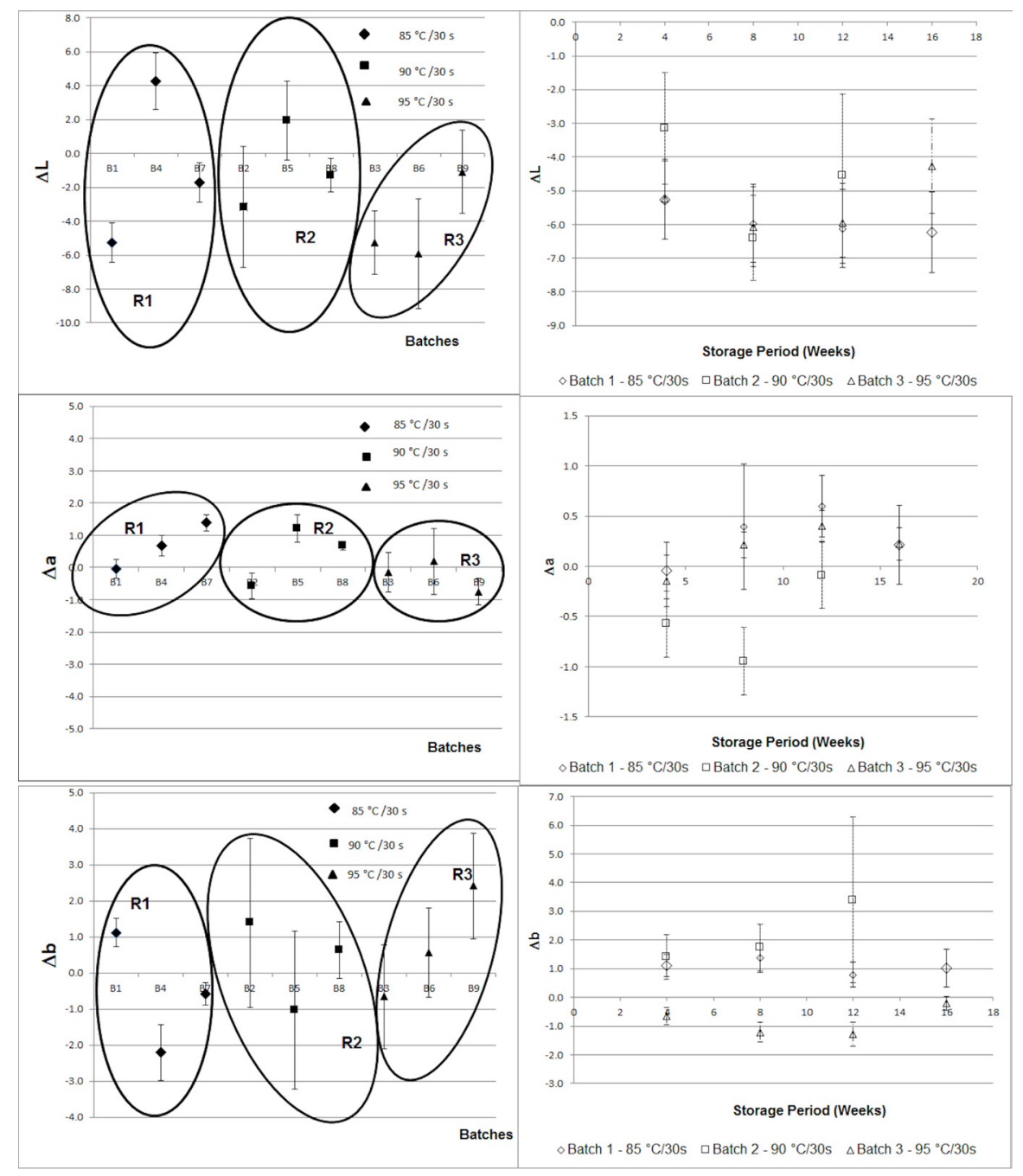

Figure 1 - Difference in CIELab color parameters during storage in relation to freshly processed beverage (a) $\Delta \mathrm{L}$ for batches 1 to 9 after 4 weeks storage (b) $\Delta$ a for batches 1 to 9 after 4 weeks storage (c) $\Delta b$ for batches 1 to 9 after 4 weeks storage (d) $\Delta \mathrm{L}$ for batches 1, 2 and 3 throughout the storage period (e) $\Delta \mathrm{a}$ for batches 1,2 and 3 throughout the storage period (f) $\Delta \mathrm{b}$ for batches 1, 2 and 3 throughout the storage period (R1, R2 and R3 refer to the replicates of processing conditions). 
Table 4 -Average of sensory acceptance scores for sugarcane juice with passion fruit pulp.

\begin{tabular}{|c|c|c|c|c|c|c|c|c|c|}
\hline \multicolumn{10}{|c|}{ Evaluated attribute (average scores / \% acceptance ${ }^{1}$ ) } \\
\hline \multirow{2}{*}{$\begin{array}{l}\text { Thermal } \\
\text { treatment }\end{array}$} & \multirow{2}{*}{$\begin{array}{l}\text { Storage } \\
\text { at } 7^{\circ} \mathrm{C} \\
\text { (days) }\end{array}$} & \multicolumn{2}{|c|}{ Appearance } & \multicolumn{2}{|c|}{ Aroma } & \multicolumn{2}{|c|}{ Flavor } & \multicolumn{2}{|c|}{ Overall Impression } \\
\hline & & Sample & Control & Sample & Control & Sample & Control & Sample & Control \\
\hline & 0 & \multicolumn{2}{|c|}{$6.0 / 92$} & \multicolumn{2}{|c|}{$6.3 / 97$} & \multicolumn{2}{|c|}{$5.8 / 95$} & \multicolumn{2}{|c|}{$5.9 / 99$} \\
\hline \multirow[t]{3}{*}{$85^{\circ} \mathrm{C} / 30 \mathrm{~s}$} & 30 & $5.7 / 87$ & $5.8 / 85$ & $5.7 / 92$ & $5.8 / 91$ & $5.4 / 92$ & $5.6 / 86$ & $5.5 / 94$ & $5.6 / 89$ \\
\hline & 60 & $4.7 / 54$ & $6.1 / 96$ & $4.6 / 54$ & $6.1 / 92$ & $4.1 / 44$ & $5.8 / 90$ & $4.4 / 48$ & $5.9 / 96$ \\
\hline & 0 & \multicolumn{2}{|c|}{$6.1 / 92$} & \multicolumn{2}{|c|}{$6.4 / 97$} & \multicolumn{2}{|c|}{$5.8 / 90$} & \multicolumn{2}{|c|}{$5.9 / 93$} \\
\hline \multirow[t]{3}{*}{$90^{\circ} \mathrm{C} / 30 \mathrm{~s}$} & 30 & $5.8 / 86$ & $6 / 92$ & $5.8 / 81$ & $5.8 / 88$ & $5.2 / 74$ & $5.5 / 82$ & $5.4 / 80$ & $5.7 / 88$ \\
\hline & 60 & $5.6 / 79$ & $6 / 92$ & $5.3 / 73$ & $6 / 93$ & $4.8 / 60$ & $5.4 / 80$ & $5.2 / 73$ & $5.7 / 86$ \\
\hline & 0 & & 91 & & 91 & & & & 88 \\
\hline \multirow[t]{2}{*}{$95^{\circ} \mathrm{C} / 30 \mathrm{~s}$} & 30 & $5.6 / 83$ & $6.3 / 96$ & $5.6 / 82$ & $6 / 95$ & $5 / 67$ & $5.8 / 93$ & $5.2 / 72$ & $6 / 94$ \\
\hline & 60 & $5.5 / 81$ & $6 / 93$ & $5.4 / 81$ & $5.9 / 86$ & $5 / 60$ & $5.7 / 84$ & $5 / 70$ & $5.7 / 92$ \\
\hline
\end{tabular}

Percentage of panelists that assigned scores above 4 . Control: juice stored at $-18{ }^{\circ} \mathrm{C}$; Number of panelists: 50 ; Serving temperature: $(12-13){ }^{\circ} \mathrm{C}$; seven-point hedonic scale: $(1=$ dislike extremely; $4=$ neither like/nor dislike; 7 = like extremely).

In this study the thermal treatment at $95{ }^{\circ} \mathrm{C} / 30$ $\mathrm{s}$ proved to be effective in maintaining an acceptable level of quality of the juice, under refrigeration, for a period compatible with the consumer market demand. The shelf life of sugarcane juice is somewhat variable and depend on the physicochemical and microbiological characteristics of raw material, processing technology, packaging system, barrier properties of the packaging material and fundamentally, the temperature of distribution, storage and commercialization. The browning and the onset of off flavors are the main factors that lead to sugarcane juice's rejection, due to chemical, enzymatic and microbiological mechanisms (Bucheli; Robinson, 1994; Yusof et al., 2000; Qudsieh et al., 2002). Apart of this, the choice of a raw material cultivar less susceptible to enzymatic browning, along with the use of proper processing technologies are highly recommended actions.

\section{CONCLUSIONS}

Complete inactivation of peroxidase in the acidified sugarcane juice required a processing temperature of 95 ${ }^{\circ} \mathrm{C}$ for $30 \mathrm{~s}$. Nevertheless, the three binomials $(85,90$ and $95^{\circ} \mathrm{C}$ for $30 \mathrm{~s}$ ) inactivated PPO. The low coliforms counts and the absence of Salmonella indicated the end product's safety. All batches of processed sugarcane juice presented a high sensory acceptance, particularly in the initial period of the stability tests. Pasteurization temperature affected sensory stability, with regard to appearance, aroma, flavour and overral impression to a large extent; an increase in temperature resulted in higher stability and a gain in product's shelf-life.

\section{ACKNOWLEDGMENTS}

The authors gratefully acknowledge the Foundation for Research Support of São Paulo (FAPESP) for funding this research, and Tecnocana Tecnologia em Cana Ltda., for providing the raw material.

\section{REFERENCES}

\section{ASSOCIATION OF OFFICIAL ANALYTICAL} CHEMISTS - AOAC International. Official Methods of Analysis. 18. ed. Chapter 11. Current through revision 2, 2007.

BRASIL. Agência Nacional de Vigilância Sanitária. Resolução RDC n 12 , de 2 de janeiro de 2001. Regulamento Técnico sobre padrões microbiológicos para alimentos.

Diário Oficial da União, Brasília, DF, 2001.

BRITO, C.A.K. et al. Características da atividade da peroxidase de abacaxis Ananás comosus ((L.) Merrill) da cultivar IAC gomo-de-mel e do clone IAC-1. Ciência e Tecnologia de Alimentos. 25(2):244-249, 2005.

BUCHELI, C.S.; ROBINSON, S.P. Contribution of enzymatic browning to color in sugarcane juice. Journal of Agricultural and Food Chemistry. 42(2):257-261, 1994. 
CAMPOS, A.D.; SILVEIRA, E.M.L. Metodologia para Determinação de Peroxidase e Polifenoloxidase em Plantas. Pelotas: Embrapa, 2003, 3p.

CROMIE, S. J. Microbiological aspects of extended shelf life products. Australian Journal of Dairy Technology. 46:101-104, 1991.

DUTCOSKY, S. D. Análise Sensorial de Alimentos. Curitiba: PUCPress. 2013, p.307-309.

GOMES, M.R.A. et al. Propriedades físico-químicas de polifenoloxidade de feijão (Phaseolus vulgaris L.). Ciência e Tecnologia de Alimentos. 21(1):69-72, 2001.

MAO, L.C.; XU, Y.Q.; QUE, F. Maintaining the quality of sugarcane juice with blanching and ascorbic acid. Food Chemistry. 104(2):740-745, 2007.

MATSUURA, F.C.A.U. et al. Aceitação sensorial de um néctar misto de mamão, maracujá e acerola. Scientia Agricola. 61(6):604-608, 2004.

PRATI, P.; MORETTI, R.H.; CARDELLO, H.M.A.B. Elaboração de bebida composta por mistura de garapa parcialmente clarificada-estabilizada e sucos de frutas ácidas. Ciência e Tecnologia de Alimentos. 25(1):147$152,2005$.
QUDSIEH, H.Y.M. et al. Effect of maturity on chlorophyll, tannin, color and polyphenol oxidase (PPO) activity of sugarcane juice (Saccharum officinarum var. Yellow Cane). Journal of Agricultural and Food Chemistry. 50(6):1615-1618, 2002.

SILVA, N. et al. Manual de Métodos de Análise Microbiológica de Alimentos. São Paulo: Varela, 536p., 2007.

STONE, H.; SIDELL, J.L. Sensory evaluation practices. London: Academic Press, 1985. p.202-226.

TEIXEIRA, E.; MEINERT, E.M.; BARBETTA, P.A. Análise Sensorial de Alimentos. Florianópolis: UFSC. 180p., 1987.

THÉ, P.M.P. et al. Efeito da temperatura de armazenamento e do estádio de maturação sobre a composição química do abacaxi cv. Smooth cayenne L. Ciência e Agrotecnologia. 25(2):356-363, 2001.

VANZO, S.P.; AZEVEDO, R.V.P. Detecção de S. aureus em manipuladores de alimentos: perfil de resistência a antibióticos e quimioterápicos. Higiene Alimentar. 17:114-123, 2003.

YUSOF, S.; SHIAN, L.S.; OSMAN, A. Changes in quality of sugarcane juice upon delayed extraction and storage. Food Chemistry. 68(4):395-401, 2000. 